\author{
A. T. Malinovskiy, \\ Candidate of Philology, \\ Associate Professor of the Department of World Literature \\ Odesa I. I. Mechnikov National University, \\ 24 / 26, Frantsuzky Blvd., Odesa, 65058, Ukraine, \\ malinowski_artur@ukr.net
}

\title{
ADAM MICKIEWICZ: IDENTITY ON THE BORDER OF CULTURES
}

\section{Summary}

A. Mitskevich's stay in Odessa is a biographical milestone that leads us to the problems of the genealogy of texts, cultural frontier and the identity of a romantic poet in imperial society and an alien mental environment.

One way or another, the period from the end of winter to November 1825 is indicative from the point of view of the psychology of transitivity, fundamental instability and the sensation of flying, hovering above the commonplace. The situation of inter-threshold, above and above the position in a rather traditionalist society, of course, reflects the psycho-physiological status of the politically unreliable Polish poet. He peculiarly mimics and appears in unexpected guises of a fluttering moth, a plucked flower, devoid of roots, not tied to tradition, environment, life, and home in the broad sense of the word. Separation from the soil is fundamentally different from the temporary shelter and the accompanying type of self-identification. He is a stranger Odessa on several parameters, primarily political, national and cultural.

The situation of a gap, atrophy of the bright, with a tendency to subject-material figurative materialization, emotional experiences, is aggravated by the play type of behavior. He consciously emphasizes his strangeness, putting on the mask of his not-his own and consistently fulfilling his intended role.

Key words: border, existential situation, imaginary, anthropological aura, petrarchism.

Надійшла до редакиії 21.09.2019 p.

УДК $82-32$

DOI: https://doi.org/10.18524/2413-0613.2019.23.183135

\section{А. Т. Малиновський,}

кандидат філологічних наук, доцент кафедри світової літератури

філологічного факультету

Одеського національного університету імені І. І. Мечникова,

Французький бульвар 24 / 26, м. Одеса, 65058, Україна,

malinowski_artur@ukr.net

\section{ГОСТИННІСТЬ В УКРАЇНСЬКІЙ ЛІТЕРАТУРІ ПЕРШОЇ ПОЛОВИНИ ХІХ СТОЛІТТЯ: РИТУАЛ - АНТРОПОЛОГІЧНА МОДЕЛЬ - КУЛЬТУРНА УНІВЕРСАЛІЯ}

У статті розглянуто гостинність як різновид соціально-рольової поведінки і як тип комунікації в українській літературі першої половини XIX століття. Феномен гостинності постає реалізацією філософії діалогу, зустрічі $Я$ з Іншим. Проаналізовано різноманітні прояви цієї комунікації в літературі, підкреслено питому вагу ритуалу, антропологічної моделі й культурної універсалії у творах. Простежено суміжні з гостинністю прояви побутової поведінки персонажів, різноманітні антропологічні коди, сценарії. Гостинність постає своєрідною антропотехнікою, що регулює повсякденне життя людини, ритуалізує їі соціальні відносини, розподіляє статусні ролі.

Ключові слова: антропологія, гостинність, соціально-рольова поведінка, Інший, ритуал.

Серед так званих антропотехнік, що презентують людську поведінку передовсім в етологічному вимірі зі стабільно-динамічним звичаєвим ладом, 
комплексом уявлень про світ, гостинність є чи не найпоказовішою. Ця категорія настільки універсальна, що в певному сенсі дорівнює таким культурно-цивілізаційним загальникам, як істина, краса, добро, буття. Усіляко маркуючись відповідно до тезаурусу епохи, звичаєвого коду і типу літератури, гостинність постає надзвичайно рухливою категорією з помітним тяжінням до порівняльної типології і розширеної семантики. В ній кодуються емблематика i знакова сфера життя, вербально-невербальна поведінка людини, дискурс спілкування з Іншим, особлива риторика впізнавання і прийняття чужого у світ свого.

На правах гостинності змінює своє обличчя й українська література перших десятиліть XIX ст., долучаючись до європейського письменства та ідентифікуючи себе як локальне утворення 3 увиразненим вектором периферійності, цілком природної для неї провінційності. Відмикаючи канали для засвоєння чужої традиції, вона гостинно поводиться 3 нею, творчо асимілює їі форми та створює власні, національні, вбудовані в рідний грунт. Це метарівень гостинності, крізь який проглядають підпорядковані йому ритуали, моделі та схеми всередині художніх творів, тобто в системі подій і образних зчепленнях. Провінційність позбавлена тут будь-якої негативної конотації і пов'язана радше 3 потужним культурним комплексом на позначення пасіонарності і впливу на формування національної ідентичності. Провінційність має свою фізіогноміку i морфологію, тому між сферою людської поведінки, почуттів, емоцій і архітектонікою простору, ландшафтом встановлюється тотожність. У контексті загальної морфології культури (термін уведений у науковий обіг німецьким культурфілософом О. Шпенглером) простір „формує душу людини, він змінюється 3 людиною. Той самий ритм пронизував ii почуття та шелест лісів" [8, с. 118]. Становлення красного письменства на території порубіжжя, національної околиці сприяло закріпленню, буквально герметизації в ньому моделей консервативної поведінки, усамітненої свідомості, цілої низки захисних реакцій на агресивне втручання зовнішнього світу. Хуторянство і провінціалізм стають необхідним 
чинником не лише письменницької поведінки, самоідентифікації, а й проектуються у площину художніх подій. Знову ж таки жодної негативної забарвленості ці комплекси не несуть, вони радше визначають поступ нашої словесності від „побутового консерватизму та місиевого, куткового nатріотизму” як „першої фази національної свідомості українських авторів доби Котляревського та Квітки" [4, с. 104]. Крім того, усамітнення, ізоляція невід’ємні від усвідомлення свого колоніального становища, яке, на противагу імперському знеособленню, суцільному нівелюванню цінностей, дозволяє зберегти традиційні форми дозвілля та унормувати їх згідно зі структуруванням національного універсуму. „Пов’язана з цим захисна настанова на локалізацію та ізоляціонізм передбачала переформування картини світу в цілому, вимагала структурних змін - не лише зменшення масштабів, але й заміни пріоритетів, полярного зміщення позицій, ідеологізації розбіжних точок зору” [1, с. 16].

Продукуючи різноманітні форми гостинності як верифікації антропологічної сутності в соціально-рольовій поведінці, численних побутових сценаріях і суспільних діях, українські письменники майже одностайно збігаються в іiі потужній моделюючій функції. Причому означені нами межі цього комплексу є відносними і радше втілюють різні його аспекти. Справді, немає посутньої різниці між старосвітським ритуалом, антропологічною моделлю і літературною універсалією, позаяк вони постають у відносинах доповнюючої дистрибуції, семантичного нюансування відтінків цього потужного універсально-знакового комплексу. Художні тексти маркують гостинність і на макро-, і на мікрорівні, від окремих метафор, образів, мотивів до розгорнутих у часі й просторі ритуалів та етикетних церемоніалів. Польський дослідник Адам Пісарек пропонує розрізняти ситуативний, оказіональний та інституціональний, категоріальний виміри гостинності у відповідних контекстах: „Необхідно відокремлювати популярне, але вторинне й метафоричне використання від того, що пов'язує гостинність 3 інституцією, в межах якої вона постає однією з основних вартостей і одним із засадничих нормативних індикаторів та водночас виконує суворо визначену функцію i 
містить ввесь набір зразків, шаблонів і дотичних до них стратегій їх утілення. Зразків і стратегій, що можуть бути екстрапольовані на інші дискурсивні і практичні категорії та зазнати інтерналізації” [9, с. 103].

Звісно, в чистому вигляді гостинність зустрічається рідко, це радше схема для наповнення якимось суміжним змістом, що постає таким собі субстратом, матеріалом твору. Здебільшого вона сусідить і корелює з похідними від неї або, навпаки, зумовленими нею гастрономічними кодами, тілесними практиками, ритуалами зустрічі з Іншим як чужим, інакшим, містерією пізнання не-своєї культури на порубіжжі, заглибленням і неквапливим переосмисленням усього незнайомого, утаємниченого, сокровенного. Коливання між прийняттям i відторгненням іншого світу, позицією і контрпозицією надзвичайно широкі, але майже ніколи не долають граничних точок підставової схеми, або ідеологеми: „Лише одна гостинність є гостинною” [2, с. 132]. Отже, між ідеєю гостинності та ii втіленнями виявляється неабияка розбіжність, асиметрія, яка, втім, виглядає цілком закономірною в контексті співіснування різник практик спілкування, невербальних риторик, типів комунікативної поведінки. 3 точки зору теорії дискурсних формацій В. Тюпи українська література тяжіє до ройової та рольової комунікації, що і зумовлює надзвичайно традииіоналістський характер гостинності, іiї відносну унормованість у межах патріархального соціуму, публічного й усамітненого, відкритого і закритого одночасно.

Тематизація цього комплексу відбувається частіше у координатах $Я$ - $M u$ спільнота за підтримки авторитетного, директивного Воно. Комунікація передбачає особистісно-надособистісний рівень, де індивідуальність розчиняється спочатку у колективній свідомості, що згодом скеровується владою традиції, персоніфікованої в актах і ритуалах повсякденного життя. Часто діалог між єдиною нерозчленованою міжлюдською группою (з різними образними аналогами у вигляді промовляючого на всі лади й голоси вулика, сільського сценічного майданчика 3 лубочним обрамленням завчасно розпланованих і продуманих дій учасників та іншими формами ансамблевої 
присутності людей на публіці) і представниками іншого світу, ідеології відбувається саме на рівні гостинності як певного ключа, дешифратора системи відносин у суспільстві, комунікативної поведінки, культури й філософії життя загалом. Завважимо, що зустріч колективу як монолітно зібраного тіла 3 притаманною йому соборною точкою зору, сакральним мірилом усього сущого 3 чужим, не-своїм, або своїм-чужим набуває різноманітних форм вираження у літературі - від різкого неприйняття, відторгнення до цілої містерії пізнання, навіть впізнавання і поступової асиміляції.

В цьому аспекті справжня парадигматика гостинності вишикується у „Пані Халявському” Г. Квітки-Основ'яненка. Міметична техніка розгортання матеріалу подібна до прийомів кінопоетики, що передбачають послідовну зміну картин, серійність у відтворенні традиційного ладу, подій у житті старосвітської верхівки. Письменник буквально ліпить образи, жести та рухи персонажів, які презентують окремі сцени й мікросцени твору. Настанова на візуальне схоплення усього, що проходить перед очима, майже фактурна відчутність різноманітних проявів тілесної та соціально-рольової поведінки зумовлені позицією суб'єкта оповіді, його жанровими пріоритетами, взятими 3 арсеналу усної та писемної словесності імітаційними техніками. Оповідач надягає маску простака, який вдається до стилізованих під усне мовлення мемуарів про миле його серцю старосвітське життя. Завважимо, що тактика дивакуватості, наївності, якоїсь інфантильності мала детально розроблені типологічні варіанти в українській наративній традиції і добре прислужилася Квітці в аспекті застосування до реалій минувшини. Стихія уснооповідного слова толерувала діалог між наратором i читачем у відкритих формах, без зайвого екрану, посередника, медіатора. Дистанція між ними скорочувалася, встановлювалися іноді фамільярні відносини, що свідчили про особливу довірливість українського Симпліциссімуса і впевненість у тому, що читач його зрозуміє. Цей контакт здійснюється у формі „гри с адресатом оповіді - через узнавання, вгадування, розшифровку натяків i відображення у подвійних 
дзеркалах" [6, с. 102]. Тому представлений світ надзвичайно відчутний i наділяється властивостями зорового, слухового, тактильного сприймання.

Кульмінаційний парад гостей у „Пані Халявському” ретельно структурований і вписаний в основний корпус тексту як цілісний ритуал 3 увиразненою соціально-антропологічною ідентифікацією. Гостинність виведена назовні, всі їі топоси словесно і понятійно номіновані, художньо оформлені, атрибутика є наочною і відповідно узгодженою з драматургією, церемоніалом. На очах читача розгортається містерія прийому гостей із низкою супровідних акцій, щоправда, без зайвої утаємниченості, інтимності. Це містерія з реалізації соціальних дій, що суворо корелюють із суб'єктами корпоративної патріархальної свідомості. Однак буде неприпустимим спрощенням зведення гостинності лише до соціального фундаменту, реалізації практичних потреб 3 обміну матеріальними і нематеріальними цінностями. У „Пані Халявському” це ще й категорія, закорінена у плоть і кров традиції, національної ментальності, етнічної психології. 3 методологічної точки зору надзвичайно важко відокремити різні аспекти гостинності як універсально-знакового комплексу.

На думку С. Зєнкіна, існує два основних різновиди гостинності: не опосередкований зайвою нормативністю, рольовими відносинами, штучними поняттями ритуал традиційних суспільств і протилежна йому ігрова поведінка 3 різноманітною метафорикою переосмислення, вигаданими сценаріями, специфічною мовою і загальними місцями. Обидві моделі співвідносяться між собою як прагматична, життєво необхідна і непрагматична, окультурена, усіляко текстуалізована і потрібна для ілюстрації чогось іншого, більш загального, не пов'язаного безпосередньо 3 фігурами господаря i гостя. Опозиція антропологічної і літературної моделей гостинності є відносною, часто-густо ці поняття функціонують як синтетична цілість. Загальну схему гостинності можна уявити як взаємодію свого і чужого: „... отримувач-гість присутній на території та / або у спільноті його подавців-господарів як „чужий” і включається в їхнє життя саме як чужий, не асимілюючись” [3, с. 181]. Культура кордонів, семантика розрізнення i відмежовування слугує 
надзвичайно необхідним інструментарієм в аналітиці гостинності. Тому осібно акцентується увага на відмінностях, своєрідності, структурній маркованості персональних сфер учасників акту гостинності, що прочитується як певний текст, закодована знаками тубільного походження система. Так само, як текст містить формальні елементи початку i кінця, архітектоніка гостинності складається з ,ритуалів прийому і проводів, тобто відмічені моменти протягом часу, коли драматично розігрується i тимчасово нейтралізується основоположна опозиція „своє / чуже”; у ході цих ритуалів гість стає „своїм чужим”, „освоюється” чи „присвоюється” господарями...” [3, с. 182]. У цій комунікації культурне і не-культурне, прагматичне і літературно-фікційне співіснують, об'єднуючись у ситуації зустрічі $Я$ з Іншим, взаємопізнання і толерування міжсуб’єктних, міжнаціональних, міжнародних контактів.

Надзвичайно структурований і прозорий, побудований на опозитивних відношеннях ритуал прийому і проводів гостей уводиться Квіткою не лише як увертюра i фінальна частина розкішного бенкету. У цьому обрамленні відчитується набагато ширша семантика, пов'язана 3 функціонуванням культурної традиції і кодуванням ï у текстових глибинах. Через гостинну ритуальність і атрибутику проглядають ритми, темпоральність і знакові прикмети етнічної психології козацької верхівки XVIII - першої половини XIX століть. Усе наочно продемонстроване письменником $є$ цілісним текстом, що ретранслює культурний тип, тяглість традиції, генеральні тезаурусні конструкції. За Ю. Лотманом, традиція безпосередньо пов'язана 3 „механізмом перекодування”, тому вона $є$ „системою текстів, що зберігаються у пам'яті даної культури, або субкультури, або особистості. Вона завжди реалізована як окремий випадок, щуо розглядається як прецедент, норма, правило. Тому „традиція” піддається більш широким інтерпретаціям, ніж „сучасність”. Текст, який пропускається крізь код традиції, - це текст, який пропускається крізь якісь інші тексти, що виконують роль інтерпретатора" [7, с. 210].

Відтворений простакуватим оповідачем світ подвійно кодований, бо на власні суб'єктивні враження та емоції накладається все ж таки сфера денотатів, 
того, що було реально і що слугувало фундаментом для тієї епохи. Крім того, відновлена у пам'яті Трушка Халявського драматургічна послідовність із симетричним чергуванням актів бенкету, ретельна деталізація, прискіплива увага до самого церемоніалу підготовки, зустрічі і проводжання гостей свідчать про орієнтацію на загальні місця літературного застілля цієї доби. Зі свого боку сучасні автору тексти ретранслюють барокову традицію з ії тяжінням до гіперболізації, нагромадження, карнавального гротеску. Будь-які повсякденні реалії в естетиці бароко перетворювалися на справжній церемоніал 3 домішками пихатості і демонстрацією надмірності. Така тернарна структура, що складається 3 власного, дещо наївного i очищеного від культурноцивілізаційних туманностей бачення, денотатів 3 прирощеними до них в уяві наратора конотативними смислами і традиційних схем літературного бароко, сприяє створенню місткого образу розкішної учти з обов'язковим дотриманням правил, етикету: „И что это были за банкеты!.. Куда! В нынешнее время и не приснится никому задать такой банкет, и тени подобного не увидишь; а еще говорят, что все вдалися в роскошь! Да какая была во всем чинность и регула!..” [5. с. 13].

Гостинність у літературі постає потужним ритуальним комплексом, крізь призму якого вибудовується уявлення про тезаурус епохи, загальні тенденції розвитку культури. Вона поєднує в собі ознаки ритуалу, антропологічної моделі і культурної універсалії, актуалізуючи в конкретних текстах індивідуальний набір значень і дотичних до них шляхів утілення практик повсякдення. Твір Квітки-Основ'яненка відтворює принципово важливі для української літератури перших десятиріч XIX століття способи взаємодії персонажів зі світом, ілюструє ситуації зустрічі суб'єкта з об'єктом на рівні потужних ритуальних комплексів та універсально-знакових моделей.

\section{Список використаних джерел та літератури}

1. Сентиментальна „провінція” (Нова українська література на етапі становлення). Харків: [б.в.], 2006. 322 с. 
2. Делез Ж., Гваттари Ф. Что такое философия?; пер. с фр. С. Н. Зенкин. М. : Институт экспериментальной социологии. СПб.: Алетейя, 1998. 287 с.

3. Зенкин С. Н. К антропологическому и литературному определению гостеприимства. Работы о теории. М. 2012. С. 179-191.

4. Зеров М. Українське письменство; упоряд. М. Сулима. К. : Вид-во Соломії Павличко „Основи”, 2003. 1301 с.

5. Квітка-Основ'яненко Г. Ф. Зібрання творів у 7 т. Т. 4. К.,1979. С. 7-197.

6. Лескинен М. В. Жанровые классификации и проблема адекватности читательского восприятия. Из истории критики и рецепции романа Григория Квитки-Основьяненко „Пан Халявский”. Человек-твореи в художественном пространстве славянских культур. М., СПБ., 2013. C. $102-127$.

7. Лотман Ю. М. Семиосфера. Культура и взрыв. Внутри мыслящих миров. Статьи. Исследования, заметки. Ю. М. Лотман. СПб, 2000. С. 12-149.

8. Шпенглер О. Закат Европы. Минск. 1999. 720 с.

9. Pisarek A. Gościnność polska. O kulturowych konkretyzacjach idei. Katowice: grupa kulturalna.pl, 2016. $264 \mathrm{~s}$.

\section{References}

1. Sentymentalna „provintsiia” (Nova ukrainska literatura na etapi stanovlennia). Kharkiv : [b.v.], 2006. $322 \mathrm{p}$.

2. Delez Zh., Gvattari F. Chto takoe filosofiya?; per. s fr. S. N. Zenkin. M. : Institut eksperimental'noy sotsiologii. SPb. : Aleteyya, 1998. 287 p.

3. Zenkin S. N. K antropologicheskomu i literaturnomu opredeleniyu gostepriimstva. Raboty o teorii. Moskva. 2012. P. 179-191.

4. Zerov M. Ukrainske pysmenstvo; uporiad. M. Sulyma. K. : Vyd-vo Solomii Pavlychko „Osnovy”, 2003. $1301 \mathrm{p}$.

5. Kvitka-Osnovianenko H. F. Zibrannia tvoriv u 7 t. T. 4. K., 1979. P. 7-197.

6. Leskinen M. V. Zhanrovye klassifikatsii i problema adekvatnosti chitatel'skogo vospriyatiya. Iz istorii kritiki i retseptsii romana Grigoriya Kvitki-Osnov'yanenko „Pan Khalyavskiy”. Chelovek-tvorets v khudozhestvennom prostranstve slavyanskikh kul'tur. M., SPB., 2013. P. 102-127.

7. Lotman Yu. M. Semiosfera. Kul'tura i vzryv. Vnutri myslyashchikh mirov. Stat'i. Issledovaniya, zametki. Yu. M. Lotman. SPb, 2000. P. 12-149.

8. Shpengler O. Zakat Evropy. Minsk. 1999. 720 p.

9. Pisarek A. Gościnność polska. O kulturowych konkretyzacjach idei. Katowice: grupa kulturalna.pl, 2016. $264 \mathrm{~s}$. 


\author{
A. T. Malinovskiy, \\ Candidate of Philology, \\ Associate Professor of the Department of World Literature \\ Odesa I. I. Mechnikov National University, \\ 24 / 26, Frantsuzky Blvd., Odesa, 65058, Ukraine, \\ malinowski_artur@ukr.net
}

\title{
HOSPITALITY IN UKRAINIAN LITERATURE IN THE FIRST HALF OF THE XIX CENTURY: RITUAL - ANTHROPOLOGY MODEL - CULTURAL UNIVERSAL
}

\begin{abstract}
Summary
Hospitality is considered as a kind of social-role behavior and as a type of communication in Ukrainian literature of the first half of the nineteenth century. The phenomenon of hospitality is the realization of the philosophy of dialogue, meeting I with the Other. Various manifestations of this communication in the literature are analyzed; the specific importance of ritual, anthropological model and cultural universality in the works is emphasized. Hospitality is a kind of anthropotechnics that regulates a peron's daily life, ritualizes their social relations, and distributes status roles.

Among the so-called anthropologists who present human behavior first and foremost in an ethological dimension with a stable and dynamic habit, a complex conception of the world, hospitality is perhaps the most indicative one. This category is so common that it is in some sense equal to such cultural and civilizational universals as truth, beauty, good, being. It encodes the emblem and sign sphere of life, the verbal / non-verbal behavior of a human, the discourse of communication with the Other, the special rhetoric of recognizing and accepting another into their world.
\end{abstract}

Key words: anthropology, hospitality, social-role behavior, Other, ritual.

Надійчла до редакиії 29.08.2019 p.

УДК 81'42:398.332.416(=161.2):316.346.2-055.2

DOI: https://doi.org/10.18524/2413-0613.2019.23.183136

О. В. Яковлєва,

доктор філологічних наук, професор кафедри загального та слов'янського

мовознавства філологічного факультету

Одеського національного університету імені I. І. Мечникова,

Французький бульвар 24/26, м. Одеса, 65058, Україна,

olga.yakovleva.1920@gmail.com

\section{ГЕНДЕРНИЙ СТЕРЕОТИП ФЕМІННОСТІ В КОНТЕКСТІ РИТУАЛІВ НА РІЗДВЯНІ СВЯТА В УКРАЇНСЬКІЙ ТРАДИЦЙНІЙ КУЛЬТУРІ}

Відповідно до актуальних понять у межах лінгвістичної гендерології - фемінна тендерна поведінка і маскулінна - основна увага у статті приділяється проявам стереотипу фемінності у ритуальних магічних діях дівчат і жінок на різдвяні свята в Україні. Описані та проаналізовані символічні значення окремих предметів та магічних дій, які були обов'язковими напередодні Різдва. У представленій розвідці виділяються і пояснюються „нелогічності” у виконанні деяких магічних ритуалів, які у традиційній культурі вважаються суто жіночими, зокрема, долучення чоловіка до захисних магічних дій. Відмічається аксіологічний аспект у виконанні ритуалів на різдвяні свята, акцентується увага на елементах руйнації гендерних стереотипів у наш час.

Ключові слова: гендерний стереотип, фемінність, маскулінність, ритуал, Різдво, імітативна магія. 